\title{
Remembering the Age of Iron
}

Television dramas about Chinese workers in the socialist era

\section{Wanning Sun}

\section{(2) OpenEdition}

\section{Journals}

Electronic version

URL: http://journals.openedition.org/chinaperspectives/6707

DOI: $10.4000 /$ chinaperspectives. 6707

ISSN: 1996-4617

\section{Publisher}

Centre d'étude français sur la Chine contemporaine

\section{Printed version}

Date of publication: 1 June 2015

Number of pages: $33-41$

ISSN: 2070-3449

\section{Electronic reference}

Wanning Sun, « Remembering the Age of Iron », China Perspectives [Online], 2015/2 | 2015, Online since 01 January 2017, connection on 28 October 2019. URL : http://journals.openedition.org/ chinaperspectives/6707; DOI : 10.4000/chinaperspectives.6707

(C) All rights reserved 


\title{
Remembering the Age of Iron
}

\author{
Television dramas about Chinese workers in the socialist era
}

WANNING SUN

\begin{abstract}
Over the past few years we have witnessed a minor cultural phenomenon in China, with the production and enthusiastic reception nationwide of several television dramas about Chinese workers in the socialist decades. Set in the industrial plants of Liaoning in China's northeast, once the industrial powerhouse of the socialist nation, these drama series centre on the dramatic transformation in workers' experiences from 1949 to the start of economic reforms. In this paper I explore these series, asking: what does the smallscale production but enthusiastic reception of this genre tell us about the contemporary cultural politics of class? This paper addresses this question by (1) highlighting the key aspects of workers' experiences with socialism as depicted in these television narratives; (2) considering the creative agenda of Gao Mantang, the script writer of the most successful industrial-themed television series; and (3) identifying some crucial ways in which the subjectivity of workers and other social groups in contemporary Chinese society intersect to shape the cultural politics of class. This discussion shows that television dramas have indeed become the basis of a widely accessible public forum that helps forge a renewed appreciation of the moral integrity of China's working class, vent a widespread sense of injustice, and foster a certain degree of solidarity between workers and other social classes. At the same time, while television dramas about workers may hold significant potential for mobilising public support for the working class and advocating workers' interests, this discussion also suggests that so far this potential has not been fully exploited.
\end{abstract}

KEYWORDS: Chinese workers, socialist era, television drama, politics of memory.

\section{The missing figure of the Chinese worker: An introduction}

n the early 1990s, industrial restructuring saw the retrenchment of more than 60 million workers from their permanent jobs in state-owned enterprises (SOEs). For those interested in workers' welfare and labour relations in China, this was an historic moment punctuated by pain and trauma. These dramatic changes have been captured in "poignant ethnographic accounts" and with "statistical precision." (1) However, details of how workers experienced the first decade and a half of socialism (from 1949 to the start of the Cultural Revolution in the mid-1960s) remain relatively hazy to the Chinese of the younger generations and to scholars and intellectuals outside China. This is perhaps because, on the one hand, Chinese workers' labour and everyday lives did not become accessible as a field of study to anthropologists and social scientists until the 1980s and 1990s. (2) On the other hand, the Chinese worker in the decades of economic reforms is a marginalised figure, and this marginalisation is also reflected in their relative absence from the symbolic and discursive domain. For this reason, there is little incentive - literary, scholarly, or indeed commercial - to promote representations of earlier workers. Nor is there much interest in creating new cultural texts that revisit and remember a bygone era when the Chinese worker held a more exulted political, social, and economic position.

To be sure, literary representations of Chinese workers and with industrial themes were created in the socialist era. However, they remain relatively obscure and largely unknown to the general reading public of both the socialist and contemporary eras. To put it simply, for over half a century, there was little knowledge of how Chinese workers experienced the early decades of socialism. This gap in knowledge and awareness might well have become permanent. Ching Kwan Lee, a scholar with a long-standing interest in the labour politics of Chinese workers, points out that memories of the experiences of Chinese workers who lived through the socialist decades, especially in the early decades of the 1950s and 1960s, would eventually vanish given the vagaries of old age and the inevitable death of the workers themselves. Such a possibly irreparable blind spot in the collective memory is indeed worrying, ${ }^{(3)}$ given that contemporary workers' activism aims to reclaim a rightful place in history for Chinese workers, and to restore the political and socio-economic legitimacy once accorded to the Chinese worker.

Over the last few years, however, a minor cultural phenomenon, in the form of the production and enthusiastic reception nationwide of a number of television dramas, has gone some way towards addressing this lack. These drama series started to appear on Chinese television in the second half of the 2000s. Set in the industrial plants of Liaoning in China's northeast, once the industrial powerhouse of the socialist nation, they centre on the dramatic transformation of workers' experiences from 1949 to the start of economic reforms. Master Artisans (Da gong jiang 大工匠, 2007), for example, is a 28-episode drama series chronicling the lives of several workers in the

1. Joel Andreas, "Industrial restructuring and class transformation in China," in Beatriz Carrillo and David Goodman (eds), China's Peasants and Workers: Changing Class Identities, Gloucester, UK, Edward Elgar Publishing, 2013, p. 102.

2. See for example Lisa Rofel, Other Modernities: Gendered Yearnings in China after Socialism, Berkeley, University of California Press, 1999; Ching Kwan Lee, Gender and the South China Miracle: Two Worlds of Factory Women, Berkeley, University of California Press, 1998; Ching Kwan Lee, (ed.), Working in China: Ethnographies of Labor and Workplace Transformation, London, Routledge, 2007; Ngai Pun, Made in China: Women Factory Workers in a Global Workplace, Durham, NC, Duke University Press, 2005; Joel Andreas, "Industrial restructuring and class transformation in China," op. cit.

3. Ching Kwan Lee, "What Was Socialism to Chinese Workers: Collective Memories and Labor Politics in an Age of Reform," in Ching Kwan Lee and Guobin Yang (eds), Re-envisioning the Chinese Revolution, Stanford, CA, Stanford University Press, 2007, pp. 1-20. 
steel and iron plant in Dalian City, Liaoning Province, over five decades (from the early 1950s to 2000). Pretty Things (Piaoliang de shi 漂亮的事, 2008), a 25-episode series, concentrates on the experiences of a few workers in a blower manufacturing plant in Shenyang, another industrial city in Liaoning Province. In 2011, television viewers greeted the arrival of The Age of Iron (Gangtie niandai 钢铁年代) with a similar level of enthusiasm. Also the story of an iron and steel plant, this time set in China's most famous steelworks, Angang, in Liaoning, this 37-episode series begins one year before the founding of the People's Republic of China and finishes in 1961, the year China launched its first satellite. Evidence that viewers' appetites for television dramas with industrial themes are not yet quenched can be seen in the broadcasting, in 2013, of the 35-episode series Workers' Neighbourhood (Gongren da yuan 工人大院). This series, set in an electrical engineering plant in Liaoning Province, narrates the rise and fall of a heavy industrial plant from the socialist to the reform eras through the lens of personal drama.

However, if this outpouring of television dramas constitutes a cultural phenomenon, it is one that is simultaneously minor and paradoxical. On the one hand, television drama series with industrial themes set in the socialist past have achieved phenomenal ratings. Master Artisans, for instance, scored an impressive $6.8 \%$ during the national holiday period in the first week of May when screened on Beijing TV, when the average anticipated ratings during the national holiday period are around 3\% to 4\%. ${ }^{(4)}$ When the series was screened on Harbin TV, a municipal TV station in northeast China, the station was so overwhelmed by popular demand that it decided on an immediate re-run. The series attracted audience groups of all ages, but was particularly popular with middle-aged and elderly viewers. On the other hand, the popularity of these shows by no means suggests that industrial-themed television dramas are a dominant or even common genre. In fact, the opposite is true. China currently produces about 15,000 episodes of television drama per year, but fewer than 100 episodes are about industrial workers. ${ }^{(5)}$

Television drama is a global television format. In some cultures it is referred to as soap opera, especially when dealing with domestic themes and personal lives. By definition, television drama series are episodic, ranging from 25 to 40 episodes. Each episode is usually half an hour to one hour long, and the series develops multiple narrative lines across multiple episodes. In China, television did not become a household medium until the 1980s. Today, it is the most affordable means of entertainment for the Chinese population. Around 30\% of China's television content consists of television drama series. ${ }^{(6)}$ Some have argued that its serial mode of story-telling resonates with the traditional modes of story-telling in Chinese culture. ${ }^{(7)}$ Chinese television drama series tend to be broadcast every day, sometimes two episodes in a row. Research also suggests that television drama is the favourite genre among rural, elderly, female viewers and audiences of lower socio-economic status, ${ }^{\left({ }^{8}\right)}$ categories into which many retrenched factory workers fall. It is therefore perhaps not surprising that industrial-themed dramas set in the socialist decades are popular among middle-aged and elderly viewers.

Television drama series about workers in the "recent history" of the socialist decades can be considered a sub-category of "history soap operas" (lishi dianshiju); other sub-categories include ancient history, modern history, and contemporary history. More than other entertainment genres on Chinese television, history soap operas are subject to a regulatory framework that involves a three-tiered (central, provincial, local) structure and multiple layers of review, featuring interconnection between the state, the Party, and military institutions of content management. ${ }^{(9)}$ Since "recent his- tory" deals with the first three decades of Communist rule (1949 to 1979), it is considered to be full of "potential landmine topics which cannot be talked about openly," and is therefore particularly subject to scrutiny. ${ }^{(10)}$

Given this context, the popularity of these series raises many intriguing questions. How do we make sense of the enthusiastic reception of television dramas with industrial themes set in the socialist era? Why are they produced? And how do they resonate with today's viewers? How do these drama series remember workers' lives and experiences in the socialist decades? And finally, but perhaps most importantly, what does the smallscale production but enthusiastic reception of this genre tell us about the role of the cultural worker in shaping the contemporary cultural politics of class? In this paper, I address these questions by pursuing three related lines of inquiry. The first identifies the key aspects of workers' experiences with socialism as highlighted in these television drama narratives. ${ }^{(11)}$ The second considers the creative agenda of Gao Mantang, the script writer of all the industrial-themed television dramas mentioned above, in order to explore how today's "cultural workers" profit from the tension between a collective nostalgia for a bygone era and a contemporary neoliberal cultural-economic logic. (12) Finally, by reading these drama series in conjunction with viewers' responses, I explain the popularity of these television narratives, and identify some crucial ways in which the subjectivity of workers and other social groups in contemporary Chinese society intersect to shape the cultural politics of class as we know it today. ${ }^{(13)}$ My objective is different from, and much more modest than, what conventional audience research methods aim to achieve. Instead of face-to-face interviews with viewers, I rely on news reports, ratings, and various online commentaries as a way of indicating the popularity of the drama series, as well as gesturing towards their usefulness in fostering cross-class solidarity.

\section{Remembering the Golden Age}

Most of the above-mentioned series span five decades and detail the changing fate of industrial workers as individuals as well as the collective

4. Xia Feng, "Sun Honglei xijukan zhizhui Zhao Benshan, Dagongjiang shoushilü gao" (Sun Honglei is as good a comedian as Zhao Benshan, and Master Artisans achieves high ratings), Beijing Chenbao (Beijing Morning News), 9 May 2007, yule.sohu.com/20070509/n249916343.shtml (accessed in September 2014).

5. "Gangtie Niandai Gao Mantang: yinping buneng wangji canye gongren" (Gao Mantang and The Age of Iron: Silver screen should not forget industrial workers), Jin Wan Bao, 28 December 2010, zt.uusee.com/gtnd/2010/1228/742.html (accessed in September 2014).

6. Ying Zhu, Michael Keane and Ruoyun Bai, "Introduction," in Ying Zhu, Michael Keane and Ruoyun Bai (eds), TV Drama in China, Hong Kong, Hong Kong University Press, 2008, p. 1.

7. $\quad$ Ibid., p. 4

8. Yuezhi Zhao, Communication in China: Political Economy, Power and Conflict, Lanham, MD, Rowman \& Littlefield, 2008.

9. Matthias Niedenführ, "The Tug-of-War Between Regulatory Interventions and Market Demands in the Chinese Television Industry," The Political Economy of Communication, Vol. 1, No. 1, 2013, accessed from www.polecom.org/index.php/polecom/article/view/14/133.

10. Ibid.

11. My discussion is informed by my viewing of all these series mentioned, but for the sake of coherence, I will focus on the more popular series, i.e., Master Artisans (2007), The Age of Iron (2011), and to a lesser extent, Workers' Neighbourhood (2013).

12. My discussion of Gao Mantang draws on his various statements published in Chinese newspapers, and my use of this material is qualified by the possibility that these statements are influenced by the purview of these publications and agenda of the scriptwriter himself.

13. There is no space here to address the topic of class and class formation in China. Suffice it to say this discussion on the cultural politics of class is informed by some key texts on class in China, including David. S. G. Goodman (ed.), The New Rich in China, London, Routledge, 2008; Minglu Chen and David S. G. Goodman (eds), Middle Class China, Cheltanham, UK, Edward Elgar, 2013; and more recently, David S. G. Goodman, Class in Contemporary China, Cambridge, UK, 2014. 
fate of the state-owned enterprises (SOEs). Although the stories are shot through with personal rivalries, love, loss, and family dynamics, these dramas unfold both on the factory shop floor and in the workers' private space, chronicling their interactions with co-workers, families, relatives, and cadres. Dynamics of personal relations are played out when workers are engaged in production on the factory shop floor. They also unfold when workers are engaged in everyday activities in the workers' communal areas and in the intimate space of the home. And protagonists' destinies are enmeshed in the grand narratives of building a new socialist modernity. The production of iron and steel, the generation of electricity and the manufacturing of machines on a massive scale all provide the most spectacular mise en scène for the playing out of narratives of friendship, love, desire, rivalry, and jealousy.

On the whole, these series remember the socialist decades, especially from the early 1950 s to the early 1960s, with particular affection and nostalgia. The series suggest that being a worker in a SOE meant job security, equality in wages, the political power of the workers over cadres, pride in one's skills in the factory, and dedication to the nation's development. Unlike workers in the neoliberal era, who are mostly represented as sources of cheap labour, lacking skills and technical knowledge, bereft of a modern outlook, ${ }^{(14)}$ and inferior in "personal qualities" (suzhi), (15) workers of the socialist era are portrayed as outstanding citizens of the nation, possessing skills, occupational competence, and an exemplary work ethic.

A common theme permeating all these industrial-themed dramas is an immense pride in the occupational skills associated with being a worker in a heavy industry plant. In both Master Artisans and Workers' Neighbourhood, for instance, the story centres on the vicissitudes of a small group of Level 8 "master artisans." Viewers are told that Level 8 represents the pinnacle of excellence in artisanship, and that in the early years of socialism, workers at this level were referred to as "artisans" (gongjiang) rather than "workers" (gongren). Although these individuals are workers (gongren) in terms of their social identity and professional grouping, they enjoy an elevated status in the factory due to their virtuosity in their crafts. In both Master Artisans and Workers' Neighbourhood, the protagonist artisans are called upon to solve technical problems and trouble-shoot mechanical glitches. The series show them drawing on experience and exercising judgement. They are portrayed as possessing exceptional ability and often secret skills on which the smooth operation of the machine depends. Workers, cadres, and engineers alike look up to these artisans with a mixture of admiration and reverence, and their opinions are respectfully sought by factory cadres.

The artisan in these series is a polymorphous figure; he combines the work ethic and moral strength of a "veteran worker" (lao gongren), the magical touch and professional acumen of a traditional master (da shi), and the knowledge and expertise of a modern engineer. In both series, the litmus test of an artisan's skill is his ability to straighten a warped steel axle - a task that is depicted as requiring a combination of expert knowledge, technical skill, and craftsmanship, as well as some kind of inexplicable, magical touch. Mundane moments where overall-clad workers go about their tasks and problem-solve on the shop floor are transformed into rarefied occasions, whereby a master worker's virtuosity is put on display to the admiring gaze usually reserved in the popular culture of the post-Mao era for gold medallists in sports, celebrities, and successful business people. These axlestraightening routines are turned into a kind of spectacular ritual; straightening the axle with an enormous hammer obviously involves hours of

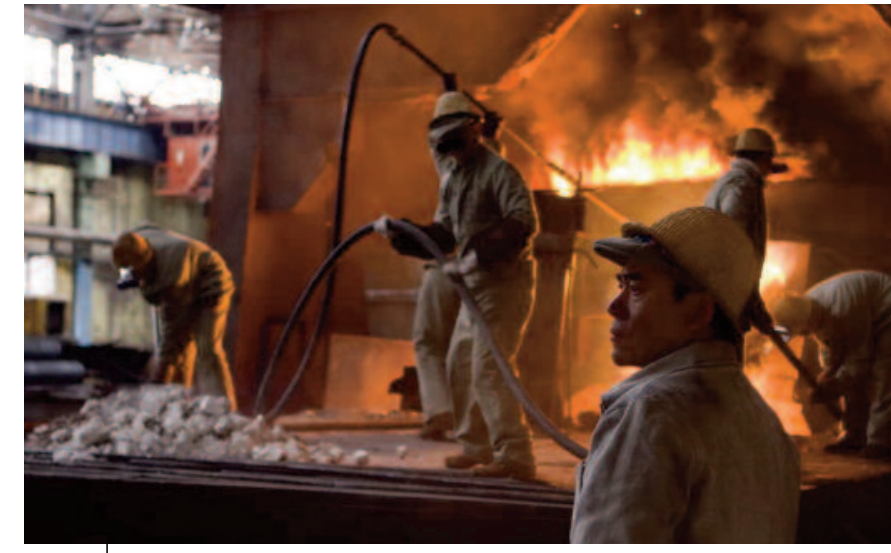

Image 1 - Image of a steel plant shopfloor from The Age of Iron (2011). @ Shandong Film \& TV Media Group

"getting to know the axle," and requires a stroke of genius as well as physical strength. Performing the task with the intensity and concentration of a concert musician, and under the incredulous and admiring gaze of co-workers, apprentices, and factory cadres, the artisan evinces supreme confidence and acumen.

In stark contrast to representations of workers written during the Cultural Revolution, which stressed class struggle and class enemies, ${ }^{(16)}$ there are no class enemies or saboteurs of socialist causes in these series. There are only very skilled and less skilled workers, all of whom are immensely proud of their status as workers and acutely aware of the importance of their work. In these narratives, workers demonstrate their self-worth through recurrent factory-organised or shopfloor competitions that test the skills and techniques of contestants. It is made clear to viewers that in those days it was not money or individual achievement that won recognition and validation from one's superiors and co-workers, nor were those the object of one's romantic desire. To workers of that era, success was never about how much money one made for oneself or the company, or how quickly one climbed the corporate ladder, as one often finds in the narratives of "successful people" (chenggong renshi) in the reform era. Instead, it was the demonstration of one's occupational skills and capacity to embody the quintessential collective quality of a worker. In Workers' Neighbourhood, male protagonist Lu Zhenghai, a Level 8 artisan, arrives on the scene, much to the excitement of everyone in the neighbourhood, including the young single women in the dormitory. Among his admirers is Yang Yuhuan, a pretty doctor who works in the factory clinic. Yang is herself actively pursued by the plant's general manager, the most privileged and powerful figure at the plant. However, she resolutely declares her love for Lu, despite the fact she is much better educated than her object of desire.

All these series about workers at that time never make clear to viewers how much workers earned in the first decade of socialism, nor does this seem relevant or important. What is made clear is that workers enjoyed equality. Xiao Changgong, the venerated worker in Master Artisans, is a veteran worker of exceptional skills and exemplary conduct. He lives in a pleasant, free-standing house surrounded by trees and a garden, a property that

14. Ngai Pun, Made in China: Women Factory Workers in a Global Workplace, op. cit.

15. Hairong Yan, New Masters, New Servants, Durham, NC, Duke University Press, 2008.

16. Xiang Cai, Geming/xushu: Zhongguo shehuizhuyi wenxue - wenhua xiangxiang (1949-1966) (Revolution/Narrative: Cultural and literary imaginary in socialist China [1949-1966]), Beijing, Peking University Press, 2010 
had accommodated foreigners in earlier days. In Episode 7, Xiao goes to Beijing and demonstrates his technical skills to Chairman Mao. Over a banquet to welcome model workers hosted by Mao in Zhongnanhai (where top national leaders including Mao reside), Mao asks Xiao what kind of house he lives in, and how many square meters it is. When he learns that Xiao's house is more than 200 square meters, Mao is impressed and says, "Your house is bigger than mine! This is wonderful! Your factory leader has done the right thing. Of all people, workers should live in the best houses."

In both series, the plants are designated strategic sites, charged with the production of premium-quality steel for national defence projects. Workers are not allowed to ask questions about the details of the projects, such as what secret weapons will be built and for what purposes, although it is hinted to viewers that the top-quality steel will be used to build submarines and rockets. Cadres and workers in these stories ask no questions. Immensely proud to be the "chosen one" for China's priority nation-building project - dubbed "Project 01 " - they devote themselves to the collective cause, working around the clock with the whole-hearted support of their families. Much to his disappointment, artisan Yang Laosan in Master Artisans is initially excluded from joining Project 01 due to his somewhat shady family connections - his father is suspected of having worked for the Japanese in the past, and he has a distant relative who fled to Taiwan. However, despite this exclusion, and keen to make a contribution, Yang works on the sly alongside the team, offering his expertise and experience. Eventually he convinces the project leaders that he is trustworthy and pivotal to the successful completion of the project, and is invited to join (Episode 12). The enthusiasm and dedication demonstrated by all characters is palpable.

Of course, workers' experiences of socialism were not entirely positive. Although the dominant tone in the series is one of nostalgia for an age of innocence, there is a certain degree of ambivalence about China's socialist past. For instance, the Great Leap Forward is remembered as a time when irrational political behaviour ruled, and the Cultural Revolution as a period of madness and violence. But these political movements are not remembered with bitterness; the madness and violence merely provide the backdrop against which workers' everyday lives unfold. Even in the middle of these erratic moments, workers are portrayed as identifying completely with the factory, and through the factory, with the collective goals of the nation. For example, during the Cultural Revolution, production comes to a standstill on the shop floor, and machines lie idle for some time. Artisan Xiao Changgong is deeply disturbed by this. Secretly gathering a few coworkers and engineers at his house, Xiao initiates a discussion about how to protect the machines in the factory and prevent them from being vandalised by political radicals (Episode 16). He asks his co-workers rhetorically and passionately: "What are workers without being able to work? What is a factory without machines? We produce iron and steel. These are the materials that build the backbone of our new nation. How can we stop?"

Watching these series, viewers get the impression that during the socialist era the meaning of work was not associated with wages or bonuses. It was instead motivated by an absolute commitment and dedication to the nation's collective goal of nation-building through the command economy. This was the case even in the most difficult times, such as during the famine of the late 1950s and early 1960s. The series do not ask what caused the famine or who was responsible, and workers are shown to be unquestioning and accepting of the Party, the government, and Mao himself. Instead of a source of bitterness, food - or the lack of it - becomes another prism through which workers show their sterling moral integrity. In the three-year famine, many workers go to work hungry; some even faint on the shop floor, but they keep on working. They tell themselves that the famine was caused by the Soviet Union's betrayal and its withdrawal of support from China. They remind themselves that they should trust the Party and Mao to see the nation through these hard times and that China will come out of the famine soon. In the meantime, everyone must be prepared to make sacrifices, just like Chairman Mao himself, who, the viewers are told by the characters, had stopped eating meat during the days of famine in solidarity with his people. This lack of bitterness is in sharp contrast to the earlier revolutionary discourse, in which workers and peasants were encouraged to "speak bitterness" about their lives in the "old" China. (17)

An overriding message to take home from these drama series is that the first generation of China's industrial workers in the steel and iron plants made a contribution to the nation that was too significant to be forgotten. The series also tell today's viewers that northeast China is the birthplace of Chinese working class identity and pride, and this claim must be rightfully recognised. The first episode of the Age of Iron, set in 1949, the year when the People's Republic of China was founded, reminds viewers of Angang's place in China's socialist history of industrial modernisation. When Shang Tielong, a decorated heroic soldier, is told that he is now demobilised from the army and has been transferred to the Anshan Iron and Steel Plant, he is initially reluctant; he would prefer to continue his career as a soldier. Sensing his hesitation, his superior, says to him:

Angang (Anshan Iron and Steel Plant) is the biggest iron and steel plant in China. Nowadays, it produces half of the iron and steel in China. Iron and steel is what this new republic needs. From the planes in the sky to the trucks on the road, nothing can be built without iron and steel. Chairman Mao and the Party have told us Angang is now the nation's top priority. There are no jobs in this country more important than working in an iron and steel plant.

Shang Tielong needs no further persuasion. Throughout the series, he dedicates himself to producing the highest quality steel possible, even though the workers are told that the purpose of such steel is classified information. In Episode 37 (the last episode of the series), having successfully produced steel that meets the standards required, Shang and his colleagues are one day summoned to the manager's office, in anticipation of an imminent announcement to be broadcast on China's National Radio. Not knowing what to expect but sensing something momentous is about to happen, everyone waits excitedly by the radio. They are not let down: China has just successfully launched its first man-made satellite. The joyful Shang and his colleagues are then surprised by some even more exciting news: they learn from the plant manager and the representative of the People's Liberation Army team that the steel produced by their team has been used to produce that very satellite!

All the industrial-themed drama series mentioned so far have been written by Gao Mantang, one of China's most prolific and successful scriptwriters today. In fact, the authenticity of the series' messages owes much to the spatio-temporal specificity of the mise en scène, which captures settings familiar to Gao. Considering that economic reforms have abandoned the

17. Speaking bitterness is a political speech act often deployed by proletarian speaking subjects. Typically, the speaker reminiscences about a previous life of bitter suffering at the hands of landlords and capitalists, and in doing so, contrasts it with the good life made possible by the Chinese Communist Party. See Ann Anagnost, National Past-Times: Narrative, Representation, and Power in Modern China, Durham, NC, Duke University Press, 1997. 
socialist industrial heartland in favour of the south and the coast, ${ }^{(18)}$ and now prioritise the trope of the present and the future, ${ }^{(19)}$ Gao's return to China's northern, industrial heartland of the early socialist decades can be seen as a deliberate attempt to re-define national space and time in the popular imagination. It can also be considered a populist strategy to recoup the moral - if not political - legitimacy of the working class. Herein lies the tension and connection between a neoliberal cultural-economic logic and the possible emergence within this space of a class subject it tends to marginalise. Apart from giving colour and texture to their everyday life and work in the form of televisual narratives, Gao's construction of a working-class memory entails evoking the workers' collective desire to reclaim their role in nation-building as well as valorising their class-specific spatial-temporal sensibility. His success as a scriptwriter and producer of television drama lies in his capacity to tap into the potential demand for such "memory work." (20) He is in turn duly rewarded for creating a niche product in the market of cultural production.

\section{Between socialist nostalgia and the neoliberal cultural market}

Gao now has around 40 drama series to his name, totalling more than 1,000 episodes. He has won not only the Fei Tian (Flying in the Sky) Award, the most prestigious TV production award in China, but also the government-funded "One in Five Project" Award. (21) In 2013, Gao Mantang topped the list of the richest writers in China, with an income totalling 20 million RMB from scriptwriting fees. ${ }^{(22)}$

Despite his reputation as a writer of industrial-themed drama series, Gao is not a card-carrying left-wing intellectual with an overt political agenda to shape labour politics in contemporary China. He has a strong intellectual and emotional commitment to the workers' cause, although he has never been a worker in his life. However, he was born and grew up in an ordinary workers' family and has an intimate knowledge of workers' lives. Above all, he is a prolific scriptwriter with a good television drama script to sell, and he believes that if told well, his stories about workers will sell not despite of, but precisely because of, the marginalised socio-economic circumstances workers found themselves in during the reform era. ${ }^{(23)}$ Gao seems to know that in order to be successful, he has to manoeuvre in the nexus between the production of "main melody" and market driven products. From the point of view of the party-state, cultural and artistic works that revisit the socialist times and the experiences of the working classes are worthy engagements with "red themes." (24) After all, at least in its rhetoric, the Communist Party has not abandoned the principles of socialism. (25) However, in the eyes of potential financiers, industrial-themed television drama scripts are usually considered "rating-killers." Gao obviously does not share this view. Clearly he believes that the industrial-themed drama series need not remain a marginal genre. It did, however, take him a decade to prove his point. It was a roller-coaster ride of hopes and disappointments, with "three ups and three downs" (san qi san luo) (He Xiaonan, 2007). The production of Master Artisans took seven years, largely due to the fact that risk-averse financiers were shy of funding a script about workers. According to Gao himself, before he finally secured funding he had negotiated with a number of financiers, many of whom got cold feet at the last moment. Master Artisans was finally funded and screened nationally, achieving high ratings. At one stage, when screened on Beijing TV, it achieved an impressive rating of 6.8 - a phenomenal figure by the norms

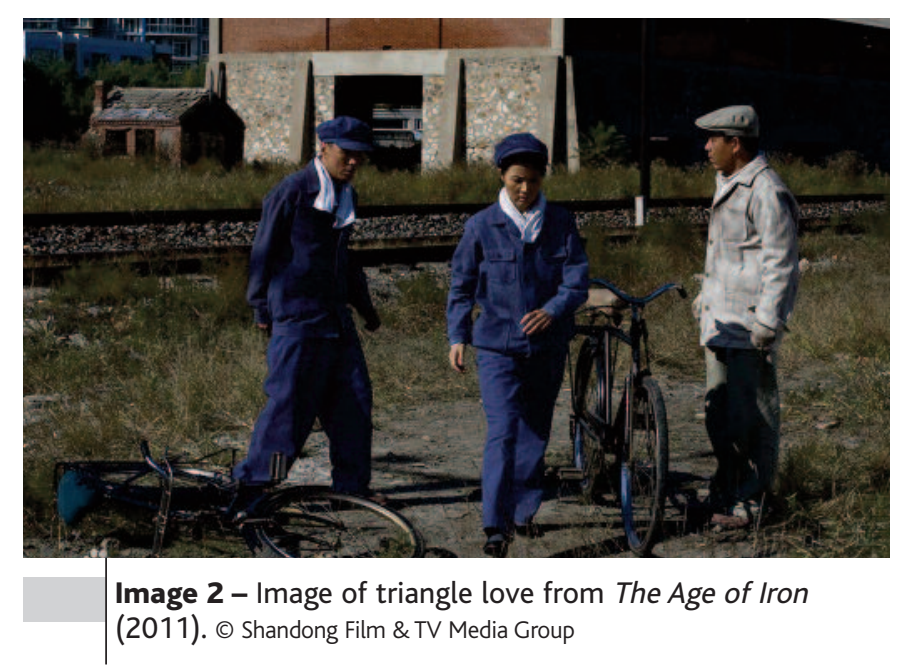

of the Chinese television industry, according to sohu.com, one of the most popular websites in China. ${ }^{(26)}$

The struggle to produce what are deemed financially risky cultural products can be relentless, but Gao maintains that as long as the story is well told and people can relate to it, industrial themed stories will rate well. After all, as he remarked in a 2011 interview, he believes that his stories resonate with 150 million Chinese workers in China today, and this figure triples if their family members are also counted. (27) When the script for Age of Iron was completed, financiers feared that the title was not marketable enough and suggested he change it to $A$ Woman Between Two Men. Gao refused. This does not mean, however, that Gao is opposed to increasing the mass appeal of his work. Instead, he seems to believe that the binary opposition between market products and "main melody" works - a term describing officially promoted and politically sound cultural products - is artificial.

18. Carolyn Cartier, Globalizing South China, Oxford, Blackwell, 2001.

19. Hai Ren, Neoliberalism and Culture in China and Hong Kong: The Countdown of Time, London, Routledge, 2010

20. Ching Kwan Lee and Guobin Yang, "Introduction: Memory, Power, and Culture," in Ching Kwan Lee and Guobin Yang (eds), Re-envisioning the Chinese Revolution, Stanford, CA, Stanford University Press, 2007, pp. 1-20.

21. The "One in Five" Project is an Award set up by the Chinese Ministry of Propaganda in 1992 to promote art and culture as part of the nation's civilisation-building project. The five domains from which the best work is selected are cinema, television, theatre, fiction, and academic research. Gao won the One in Five Project as a script writer for Hurricane Over the Sea (Da hai feng) in 1993, a film also with "industrial themes" (gongye ticai). See Shi Shaotao, "Xin shiji gongye ticai chuangzuo de jiazhi linian bianqian:Yi Gao Mantang gongye ticai weili" (Transformation of values and beliefs in the creation of industrial themes in the new millennium: A case study of Gao Mantang's industrial-themed works), Harbin Xueyuan Xuebao (Journal of Harbin University), Vol. 33, No. 5, 2012, pp. 75-77.

22. Baike, "Gao Mantang," www.baike.com/wiki/高满堂, no date (accessed in September 2014).

23. Xiaonan He, "Duihua zhuming bianju Gao Mantang: Qinian mocheng daxi" (In conversation with famous scriptwriter Gao Mantang: Creation of masterpiece following seven years' hard work), Beijing Yule Xinbao (Beijing Entertainment News), 11 May 2007, available at art.ce.cn/ylmb/ ylysj/200705/11/t20070511_11313698.shtml (accessed in September 2014).

24. Qian Gong, "A Trip Down Memory Lane: Remaking and Rereading the Red Classics," in Ying Zhu, Michael Keane and Ruoyun Bai (eds), TV Drama in China, op. cit., pp. 157-172.

25. Yingjie Guo, "Class, Stratum and Group: The Politics of Description and Prescription," in David S. G. Goodman (ed.), The New Rich in China: Future Rulers, Present Lives, London, Routledge, 2008, pp. 38-52.

26. Wen Dong, "Dagongjiang Beijing shoushilü chuangxin gao: yanyuan Zhang Xiaoxiao beishou huanying" (Master Artisans achieved unprecedented high ratings: actor Zhang Xiaoxiao is very popular with viewers), 15 May 2007, from yule.sohu.com/20070515/n250035005.shtml (accessed in September 2014).

27. Yang Xiao, "Jujiao canye gongren Gao Mantang xie gongheguo buneng wangji de renmeng" (Turning the spotlight onto the industrial workers: Gao Mantang says the nation should not forget them), Liaoning Ribao (Liaoning Daily), 1 January 2011, cul.china.com.cn/renwu/2011-01/01/content_3934151.htm (accessed in September 2014). 
In Gao's view, people assume that industrial themes are boring largely because most cultural representations of workers in the past have had two unfortunate tendencies: they either deified workers and made them superhuman and devoid of humanity (as in the plays during the Cultural Revolution), or they glorified reformers and entrepreneurs but portrayed workers in the reform era as entities with no control over their destiny and who needed to be reformed. Aware of these pitfalls, Gao's recipe for success sounds surprisingly simple: put humour, drama, and conflict into the story, contextualise industrial themes in the quotidian space of work, home, and neighbourhood, and promote familial love (qinqing), friendship (youqing), and romance (aiqing). (28)

In other words, Gao's determination to produce industrial dramas is driven as much by an entrepreneurial spirit - the trademark of a risk-taking neoliberal subject - as it is by an ideological commitment to representing the Chinese worker. Having lived through the structural transition from "cultural institutions" to "cultural enterprises" in the cultural sector, Gao has successfully managed to ride the wave of "cultural neoliberalisation" (29) instead of becoming a victim of it.

At the same time, believing that he has a duty as an intellectual and statefunded writer to represent the lives of workers, Gao feels that he has earned the capacity to claim inter-subjectivity with the workers he represents:

Every time I go into the factory, workers greet me gladly and say, "Teacher Cao, here you are again. Still want to write about us?" Some would say "Nobody writes about us these days. We are nobodies." Every time I hear them say this, I find myself choking with sadness and melancholia. Instead of discouraging me, they in fact spur my creative impulse and make me more determined to speak on their behalf. (30)

Gao believes that his family background, upbringing, and place of origin enable him to claim inter-subjectivity with workers, and imbue his representations of workers' experiences with authenticity. Born into an ordinary workers' family, and growing up in a workers' neighbourhood, Gao came to acquire an intimate knowledge of the everyday life of a worker in the socialist decades. In an interview, Gao tells the journalist that his parents and siblings were all workers, so he was not only familiar with their lives, but was also emotionally connected with them:

Writing about workers, you must draw on what you know. A young and inexperienced scriptwriter may write something like "the factory shop floor is teaming with busy workers," but a director doesn't know how to translate this description onto the screen. With industrial themes, you can't be an armchair writer and rely on your own imagination. In order to write Master Artisans, I spent, on and off, five years in the iron and steel plant in Dalian. I spent lots of time talking to workers, travelling with them on the factory bus to go to work, eating with them in the factory canteen, working with them on the factory floor. ${ }^{(31)}$

Gao thus sees himself as a self-appointed historian of Chinese workers of the socialist era. However, what sets him apart from conventional historians is his interest in exploiting television drama as a visually mediated and discursively narrated account of the past. Born and brought up in northeast China, Gao sets most of his drama series in places that are familiar to him in terms of local dialect, everyday life, and local customs. Often now dubbed China's "rust belt," this region, especially Liaoning Province, once held a preeminent place in the national imagination due to its status as China's key site for the production of iron and steel. In the reform era, however, the heavy industry in northeast China with its high concentration of SOEs went into decline. Millions of workers were retrenched. Forced into early retirement, they were demoralised and suffered enormous downward economic mobility. For Gao, to forget the contribution of China's first-generation iron and steel workers would be morally unconscionable. In a 2007 interview, Gao made it clear that he regards the absence of images of workers on television as "not a good look." As he put it, "It simply will not do to erase the presence of a group of people who exist in such significant numbers." (32) In his opinion, even in the market economy, industrial workers are still the mainstay of China's national economy, and television should give them space and a platform to speak: "We must not leave them languishing in the margins." (33)

Yet Gao seems acutely aware that there exists a political boundary beyond which it is not prudent to step. Although the series span five decades of workers' experience all the way up to the beginning of the twenty-first century, both Master Artisans and Workers' Neighbourhood fail to include workers' collective political action in the form of protests against the loss of permanent jobs and inadequate compensation on retrenchment. In fact, he does not seem willing even to gesture toward the existence of these less positive dimensions. Yet, as Ching Kwan Lee's research ${ }^{(34)}$ documents clearly, large-scale protests in the rust belt throughout the 1990s were perennial and constituted an essential part of workers' labour politics in the postMao era. Given that television drama as a cultural product must avoid both political and economic risks, it stands to reason that Gao would accommodate workers' critical voices as much as is acceptable but would leave out the workers' collective actions, which are considered controversial and potentially destabilising.

Similarly, all these series sidestep the equally well-documented reality of sporadic conflicts between workers and management. In these series, workers, managers, and cadres are represented as working towards the common goal of building a strong new nation, while in reality incidents of workers' resistance, protests, and strikes were not uncommon throughout the 1950s, particularly the second half of the decade. ${ }^{(35)}$ Another missing historical aspect key to labour politics is the workers' union. Despite criticisms of its failure to represent workers' interests and to operate as a real opposition

28. Ibid.

29. Hai Ren, The Middle Class in Neoliberal China: Governing risk, life-building, and themed spaces, London, Routledge, 2013, p. 45.

30. "Gangtie Niandai Gao Mantang: Yinping buneng wangji canye gongren" (Gao Mantang and the Age of Iron: Silver screen should not forget industrial workers), op. cit.

31. Ibid.

32. Xiaonan He, "Duihua zhuming bianju Gao Mantang: Qinian mocheng daxi" (In conversation with famous scriptwriter Gao Mantang: Creation of masterpiece following seven years' hard work), op. cit.

33. Yang Xiao, "Jujiao canye gongren Gao Mantang xie gongheguo buneng wangji de renmeng" (Turning the spotlight on industrial workers: Gao Mantang says the nation should not forget them), op. cit.

34. See Ching Kwan Lee's research, op. cit.

35. Anita Chan, "Revolution or Corporatism? Workers and Trade Unions in Post-Mao China," The Australian Journal of Chinese Affairs, No. 29, January 1993, pp. 31-61; Jackie Sheehan, Chinese Workers: A New History, London, Routledge, 1998; Aidi Gao, "Ershi shiji wushi niandai dui canye xingdong de zhengque renshi he chuli" (A correct view and approach to industrial actions during the 1950s), in Tongqing Feng (ed.), Jujiao Dangdai Zhongguo shehui laodong redian wenti (Focusing on the hot debates surrounding issues of labour in contemporary Chinese society), Beijing, China Workers' Press, 2012, pp. 175-188 
to the Party and management, ${ }^{(36)}$ the workers' union nevertheless had had a continuous presence in the everyday work and lives of workers. Despite this, its controversial political status ensures that it is not featured at all in Gao's drama series.

\section{Viewers in the inter-subjective space}

For retired or laid-off former SOEs workers, watching these stories means taking a trip down memory lane and allowing many memories to resurface. A former worker-cum-writer confessed that he had watched the Master Artisans from the "very beginning to the very end," even though he normally "watched little television apart from news." He was also moved to submit an article to the online version of the Beijing News, a popular tabloid in Beijing:

I worked in a state-owned enterprise similar to the one in Master Artisans. My time there happened to be the painful moment of enterprise restructuring, and I worked with people who are like the characters in the show. I kept thinking while watching the show: what was it in the olden days that made us workers so assured and glowing with pride and confidence, and what is it in the new era that made us feel so abandoned and lost? In those times, workers' opinions were highly sought after and respected by management; nowadays, even a young and inexperienced white-collar can shout at workers and boss them around. ${ }^{(37)}$

When journalists realised how popular these series had become, they took to the suburbs to find out why viewers liked them. Among those interviewed, a Mr. Liu said he used to be a worker in the iron and steel plant, and that his working life unfolded more or less in the same way as that of the artisans in the series. He felt a wave of nostalgia when he noticed an enamelled tin tea mug (white with bold red flowers, typical of the aesthetics of that era). Whenever he heard the theme song that closed each episode "A Bottled-Shaped Mountain" - he was instantly transported back more than half a century. The theme was a folk song from Qinghai familiar to the people who lived through the 1940s and 1950s. ${ }^{(38)}$

Taking a trip down memory lane, however, does more than scratch a nostalgic itch. It also affords one an occasion to critique the present by referring to the past. One middle-aged woman told a journalist that while young people are looking to learn from history, for her it is more about revalidating the moral and ethical conduct of the past:

All these deeds, tunes, and conversations in the drama series, we did them, we sang them, and we spoke them. This sense of the familiar goes straight to my heart. Young people may think that workers in those days were stupid, sacrificing their own limbs to save the factory's machine, or denying their own children chances to get ahead in life due to their own principles of honesty and selflessness. But in those times, that was entirely natural. ${ }^{(39)}$

It may have come as a surprise to Gao Mantang, however, to find that his stories of workers in the socialist decades also appeal to young people born in the 1990s. Judging by the responses posted online, it is clear that many young people watch these series online, and often watch many episodes in one sitting. Furthermore, they are prone to posting responses online in the form of a blog or short text on social media. While many viewers, especially the middle-aged and elderly, still like the daily rhythm of watching each episode of the drama series as it is broadcast on television, television drama series are increasingly watched online. Younger viewers in particular prefer to choose their viewing location, time, and circumstances. This change in viewing habits has profound implications for viewing-related sociality. One implication is that younger and more computer-literate viewers may be more likely to post their thoughts and feelings online rather than communicating these face to face to fellow viewers - whether family members or friends. More significantly, it means that the responses, reminiscences, and comments made by viewers, which in the past were ephemeral and addressed to only an individual listener or a small number of individuals, have now become part of the ever growing digital archive. Through these digital media, individual memories have a chance to echo and reverberate with other people's sentiments in the public domain, albeit virtually. In other words, television dramas (and their associated websites) portraying workers in a favourable light have become widely accessible public forums, and the easy accessibility of both the dramas and their digital presence fosters a certain degree of solidarity between workers and other social classes.

It can be argued that this inter-generational dialogue is crucial to the workers' fight for political, social, and economic recognition, since the younger generations tend to have more social, economic, and technological resources at their disposal, and the effective deployment of these resources is key to workers gaining wider-based moral support in their struggles for recognition. One viewer was heard remarking to a fellow viewer, "Now I know how much my parents had to endure in those years!" Another young man born in 1991 saw the show and posted a message to his friends online, encouraging them to watch Master Artisans to find out what life was like for their parents. A common way of expressing this moral solidarity with workers is by comparing today with yesterday. One young person says, "To be sure, these days, we have more freedom. We can do whatever jobs we want, date whoever we want to, and pursue our own happiness without guilt and shame. But somehow, I cannot help but feel the purity and passion demonstrated by the people in the past is no longer possible." He told his friends, "You will learn a lot about the decades in which our parents grew up." (40) A viewer identifying himself as someone "born in the 1990s" (jiu ling hou) posted a message to the actor playing Yang Shoushan, a key protagonist in the Age of Iron, saying that he has been watching the show every night in the company of his grandparents:

If I come across anything that doesn't make sense to me, I ask my grandpa and grandma. They explain it to me, drawing on their own experiences. The viewers of the Age of Iron are indeed wide-ranging. Grandpas and grandmas can see themselves when they were young,

36. Anita Chan, "Revolution or Corporatism? Workers and Trade Unions in Post-Mao China," op. cit., pp. 31-61.

37. Shinian Kancai, "Dianshiju Dagongjiang: Zhu xuanlu yejiang renqingwei" (TV drama Master Artisans proves that even "main melody" products can have human interest), Xin Jing Bao (Beijing News), 16 May 2007, accessed from epaper.bjnews.com.cn/html/2007-05/16/content_17887.htm.

38. Honglei Sun, "Dagongjiang Hashi shoushi xingao, Sun Honglei yan haoren ye chucai" (Master Artisans achieves high ratings in Harbin, Sun Honglei's performance excels even as a good guy), originally published in Shenghuo Bao (Life News), 2007, available at tieba.baidu.com/p/185961387 (accessed in September 2014)

39. Ibid

40. Wenjie Yang, "Dagongjiang ticai lengpi denglu dianshi, que yingfa guanzhong repeng" (Master Artisans is a niche topic yet it attracts enthusiastic audience response), Beijing Qingnian Bao (Beijing Youth Daily), 8 May 2007, available from www.ce.cn/bjnews/yule/200705/08/t20070508_ 11274331.shtml (accessed in September 2014). 
mums and dads can learn about the lives of their parents' generation, and youngsters like myself can learn to appreciate how our forebears built a new China. ${ }^{(41)}$

But perhaps the most significant political implication of these drama series lies in their capacity to provide a vital space for inter-subjective dialogue in class terms. In addition to giving the younger generations of viewers a chance to learn about their parents' lives, these series also seem to have the effect of making viewers - including non-workers - become more appreciative of the sacrifices older workers made. By implication, viewers are given the chance to critique the social Darwinist principle of competition unleashed in the reform era. In Episode 21 of Master Artisans, when the series progresses into the late 1980s, workers are assembled to listen to a young and entrepreneurial cadre from "above." Extolling the merits of a new and more competitive wages system, he tells workers that while everyone will be paid a basic wage, their bonus will depend on their productivity. This announcement is met with an angry response from older workers. Xiao Changgong, a model worker in Mao's era and much respected for his moral leadership, stands up and asks rhetorically, "But what about the elderly, the frail, the sick, and the disabled workers? Is it fair to expect them to compete with young workers on a level-playing field? Is it fair?"Yang Laosan, Xiao's life-long friend and co-worker on the shop floor, is even more scathing. He gets up from his seat, walks to the platform, and makes an unsolicited speech:

You've all noticed that Master Xiao has only one hand, but young people here don't know how he lost the other one. Many years ago, his hand got caught in the machine. His colleagues decided to cut open the machine in order to save his hand, but Xiao broke free from the machine by pushing away the machine with his feet. He saved the machine but lost his hand. Are there still workers like Xiao Changgong these days? How can you possibly expect him to compete with young workers today? Also, during the three-year famine, many of us had swollen hands and feet because we didn't have enough food to eat but we kept working. Members of Project 01 were offered an extra bun each day but we declined to take it. There is more. During the Cultural Revolution, our country needed steel, and we went to work on the shop floor, risking being beaten up by the young rebels. Did we ever ask the factory for money at all? Now these workers are getting old, and you think they are useless and want to dispose of them like rubbish. Is it what Marx and Engels have taught you?

Critiques such as this of market economy principles not only resonate with worker viewers, they can also be extremely effective in generating sympathy and respect for workers from other socio-economic groups. In other words, these drama series can function as a powerful spontaneous, public forum where Chinese workers' moral claims are re-asserted. It is the inter-subjectivity between workers and the sympathetic cultural elites that makes this public forum possible. This is important from the point of view of fostering cross-class solidarity. A university-educated netizen in his late 30 s confesses that this is the first time he has ever posted a comment on Tianya, a prominent online public forum, well-known among educated netizens, because he is so moved by Master Artisans that he feels compelled to share his thoughts:
Throughout the 1950s, during the three-year famine, they worked so hard and made so many sacrifices. But when it came to the reform era, enterprises had to be restructured, and they had to be retrenched. They are such wonderful workers! Unable to sustain a basic livelihood, a son of a model worker, who himself had won factory-wide contests for his skills, was also laid off. He had to make a living shining people's shoes in the street. I was choking with tears to see what has become of these workers. Towards the end, they couldn't even feed themselves. I am speechless! This drama series reminds me of my university years. I went to uni in Wuhan, also a big industrial city. Wuhan Iron and Steel Plant is one such plant, Wuhan Heavy-Machinery and Engineering Plant is another, and there is also the Wuhan Furnace Manufacturer. When I was a uni student in 1996 and 1997, I saw thousands of laid-off workers sitting on the streets, protesting to the city government, demanding to be paid. Once, I saw them sitting together in the middle of a highway! It made my heart go cold to remember those scenes. What is the point of reforms?! Every day, someone is getting richer and richer, houses are getting more and more expensive, but workers cannot even feed themselves. I am speechless! (42)

This netizen's lengthy account of his emotional and moral responses to Master Artisans points to an interesting paradox in remembering the workers' experience in the genre of television drama series. While Gao has control over what to include and exclude in his text, he has no control over who will watch it and how they will respond. Although this netizen's memory of workers' collective actions in Wuhan was triggered by his viewing of the drama series, he goes beyond the text to remind fellow viewers what Gao has left out. By making such an association, this commentary reminds us that Gao's television drama series, widely popular and deeply resonant with viewers from different social groups, are selective memories, like all historical narratives. At the same time, the viewer's comment reminds us that, through the amplifying mechanism of online technologies and social media, even relatively uncontroversial cultural texts may have uncertain and unpredictable political ramifications. Finally, in the same way that Gao's representation of the socialist decades is informed by the political, social, and economic reality of the reform era, viewers also relate to these narratives of socialism through the lens of post-socialist class politics.

\section{Conclusion}

Mass access to television means that, for the first time, the minutiae of workers' everyday experiences in earlier times can be represented, not only narratively but also visually. For the first time, stories of these workers' lives are consumed as part of the quotidian cultural diet. The cluster of television drama texts discussed here centres on the experience of Chinese workers from the socialist to the reform period, but the production and consumption of these cultural products involves intellectuals, cultural elites, and university students as well as workers. Workers and peasants may be represented as

41. Jiang Tianjiao, "Kainian daxi, handing renxin de shidai xuanlü" (The new year starts with big dramas, plucking the heartstrings with the melody of our era), Jingji Ribao (Economic Daily), 23 January 2011, available at paper.ce.cn/jjrb/html/2011-01/23/content_135749.htm (accessed in February 2015).

42. Morewu, "Kan dianshiju Dagongjiang yougan" (How I felt when viewing the TV drama Master Artisans), 2007, bbs.tianya.cn/post-filmtv-184553-1.shtml. 
the protagonists in these dramas, but the imagining and re-imagining of working class identities takes place on a much wider social canvass, involving the participation of various social groups and classes. This paper has suggested that post-socialist cultural products reject the socialist propaganda models of portraying workers as "tall," "big," and "perfect" revolutionary heroes who are devoid of personal desire and individual agency. ${ }^{(43)}$ While this is metonymic of the political and ideological shift marking the transition from Mao's era to the era of economic reforms, the emergence of television drama as a genre in the past three decades has proved to be an effective means of facilitating this shift. This investigation into the contemporary representation of a historical social identity - Chinese worker in the socialist era - dovetails with existing studies of media representation, which, so far, tend to focus on Chinese workers in the reform era. ${ }^{(44)}$ From her conversations with retired and laid off workers in Liaoning, Ching Kwan Lee concludes that workers often express their moral anger and outrage with the present by evoking memories of the equality and justice enjoyed in the past. She points out that 'in the absence of public forums for workers' articulation of their interests and for organisation of worker resistance, shared emotive and moral frameworks have come to play a heightened role in fostering solidarity." (45) This paper's analysis of the production and reception of drama series supports Lee's argument. Like oral history produced by individual workers, television dramas afford occasions to remember the socialist past, thus forming and contributing to a critique of workers' circumstances in the market economy. At the same time, in the absence of more effective public forums through which to represent workers, television dramas have emerged as the "next best thing." In the same way that literary writers can play a role as anthropologists' "wonderful ethnographic partners," (46) these retrospectively constructed televisual narratives may also shed valuable light on the everyday lives of a bygone era, even though the lens may be tinted with nostalgia and by no means free from the politics of memory. These televisually re-enacted and widely accessible memories would not have been possible without the creative impulse and the entrepreneurial energy of cultural workers such as Gao Mantang.

The role of cultural workers, however, goes further and is more complex than making these memories available to the public. As this discussion also makes clear, another noteworthy political implication of this televisual re- imagining of Chinese workers is that the process makes it possible for viewers from different social classes to share an inter-subjective discursive space, however temporarily. Television dramas portraying workers in an overwhelmingly favourable light have indeed become the basis of a widely accessible public forum, which helps to forge a renewed appreciation of the moral integrity of China's working class, vent a wide-spread sense of injustice experienced by workers, and foster a certain degree of solidarity between workers and other social classes.

Having said that, there is little in the discussion that suggests that Gao Mantang intends to reshape labour politics or facilitate pro-worker activism. On the contrary, while his sympathy and desire to identify with workers seems genuine, his artistic creations seem to function more as a social safety valve, simultaneously accommodating and defusing the anger and moral outrage of workers. In other words, his discursive strategy is informed by and consistent with post-socialist class politics. On the one hand, this class politics actively taps into a collective nostalgia for socialism and a renewed appreciation for China's working classes. On the other, the series adhere to a neoliberal logic of producing politically safe and commercially successful cultural texts. And this class politics leads to the paradoxical outcome of simultaneously articulating and dissipating the formation of class consciousness. (47) Gao Mantang's work embodies this paradox. It offends nobody - not the workers themselves, the Party-state, the Left-leaning intelligentsia, or the free-market liberals. Instead, it offers something for everyone to savour. With their capacity to reach audiences on a large scale through television and online broadcasts, and their ability to generate infinitely reproducible and enduring responses in the digital age, television dramas about workers may hold significant potential as a platform to mobilise public support for the working class and advocate workers' interests. At the same time, as this discussion suggests, so far this potential has not begun to be realised.

Wanning Sun is professor of media and cultural studies at University of Technology, Sydney.

School of Communication, Faculty of Arts and Social Sciences, University of Technology Sydney, PO Box 123, Broadway NSW 2007, Australia (wanning.sun@uts.edu.au).
43. Qian Cong, "A Trip Down Memory Lane: Remaking and Rereading the Red Classics," op. cit.

44. See, for instance, Yuezhi Zhao, Communication in China: Political Economy, Power and Conflict, op. cit. See also Wanning Sun, Subaltern China: Rural Migrants, Media and Cultural Practices, Lanham, MA, Rowman \& Littlefield, 2014. To a lesser extent and on a smaller scale, see an earlier study by Lisa Rofel, "Yearnings: Televisual Love and Melodramatic Politics in Contemporary China," American Ethnologist, Vol. 21, No. 4, 1994, pp. 700-722.

45. Ching Kwan Lee, "What Was Socialism to Chinese Workers: Collective Memories and Labor Politics in an Age of Reform," in Ching Kwan Lee and Guobin Yang (eds), Re-envisioning the Chinese Revolution, Stanford, CA, Stanford University Press, 2007, p. 160.

46. Judith Farquhar, Appetites: Food and Sex in Post-Socialist China, Durham, NC, Duke University Press, 2002.

47. Yingjie Guo, "Class, Stratum and Group: The Politics of Description and Prescription," op. cit;; see also Wanning Sun, Subaltern China, op. cit. 